\title{
Establishment of a Standard Micropropagation Protocol for the Production of Uniform Planting Material in Musa Laterita (Section: Rhodochlamys).
}

Saraswathi. M.S. ( $\square$ saraswathimse@gmail.com )

National Research Centre for Banana

J Mahendran

National Research Centre for Banana

Chinnadurai Karthi

National Research Centre for Banana

Murugesan Umabharathi

National Research Centre for Banana

Arumugam Palanivelu Salini

National Research Centre for Banana

Palani Durai

National Research Centre for Banana

Subbaraya Uma

National Research Centre for Banana

\section{Research Article}

Keywords: Musa laterita, micropropagation, transcriptome analysis

Posted Date: October 4th, 2021

DOl: https://doi.org/10.21203/rs.3.rs-938009/v1

License: (c) (1) This work is licensed under a Creative Commons Attribution 4.0 International License.

Read Full License 


\section{Abstract}

Musa laterita is one of the dwarf statured, ornamental Musa species, which belongs to the section Rhodochlamys. It is immune to Sigatoka leaf spot and Fusarium wilt diseases and also exhibits tolerance to moisture deficit stress. Among the fungal diseases, fusarium wilt especially race TR4 is highly threatening the banana industry worldwide and hence the TR4 resistant gene should be identified on priority for use in banana improvement programmes. Though, it is a wild seeded type which can be easily propagated through seeds, the off springs are not genetically uniform making it unfit for any molecular analysis. In vitro micro propagation of ornamental banana including Musa laterita is limited due to poor multiplication rates compared to commercial cultivars. Therefore, the present study was undertaken to establish an in vitro protocol for plant regeneration from shoot tip explants. Efforts were made to enhance the multiplication efficiency using MS media fortified with BAP, TDZ, NAA, IAA and IBA in different combinations so as to obtain maximum numbers of plantlets in minimum duration. The plantlets produced would be used to study the molecular mechanism behind Fusarium wilt resistance (TR4), through transcriptome analysis.

\section{Key Message}

Thidiauron (TDZ) played a significant role in the micropropagation of M.laterita, a member of the section Rhodochlamys. The tissue culture protocol developed helped in the production of uniform planting material for use in transcriptome analysis as it is said to be resistant to fusarium wilt.

\section{Introduction}

Banana is the most important and valued fruit for most population of the world. India is the largest producer of bananas in the world with an annual production of 30.5 million tonnes that accounts for $26.02 \%$ of the world's bananas production. The top five countries namely India, China, Indonesia, Brazil, and Ecuador alone account for $53.94 \%$ of the total world's production. However, the production of banana is affected by several diseases such as Fusarium wilt, Sigatoka leaf spot complex and other viral diseases. Fusarium wilt, caused by Fusarium oxysporum f. sp. cubense (Foc) was first discovered in Australia in 1874 and has now spread to different regions of the world (Jamil et al. 2019) threatening the banana industry as a whole. Though chemical control, inclusive of soil fumigation (Herbert and Marx 1990), fungicides (Nel et al. 2007) and soil amendments (Stover 1962) are in practice, only limited control could be achieved and their continuous use is likely to result in soil and environmental pollution posing risk to human health. Therefore, the alternate option is development of pest and disease resistant varieties through non-conventional breeding approaches such as in vitro mutagenesis, protoplast culture and genetic engineering (Crouch et al. 1998).

The wild Musa spp. which are mostly distributed in the North-Eastern States, the Western and Eastern Ghats of India and Andaman and Nicobar Islands (Hareesh et al. 2017) harbor genes imparting resistance to major biotic and abiotic stresses. However, many regions within its center of diversification 
i.e., North Eastern India have not been explored systematically due to various factors like their occurrence in dense evergreen forests which are inaccessible for civilians, existence of political unrest in the region, etc. So many taxa are yet to be described (Sabu et al. 2013). Musa laterita is a wild species belonging to the section Rhodochlamys well known for its slender stem, suckering profusely (4-5 nos.) 0.5 to $1.2 \mathrm{~m}$, away from parents. It has a running rhizome, asymmetrical bunch shape, axis is nearly straight, bright brick red colored bracts and hence appropriately named as Musa laterita (Natarajan et al. 2019). It is native to the Indian subcontinent (North-Eastern India) and Indo-China (Myanmar and Thailand) and frequently seen as ornamental plants in the home-gardens of Karnataka, Kerala, Assam and Meghalaya. These ornamentals possess toned upright leaves and dark midribs, and grow well in open fields with full sunlight and generally propagated by its extended rhizomes. Male flowers are orange yellow in colour, 2-3 cm long, 6-10 flowers per bract and bi-seriate (Uma et al. 2014). Most of the Rhodochlamys members are immune to Sigatoka leaf spot and Fusarium wilt diseases (Nandhakumar et al. 2018).

Transcriptome studies in banana are very much useful to study the host pathogen interaction between Musa with Sigatoka (Passos et al. 2013), root lesion nematode (Kaliyappan et al. 2016) and Fusarium (Wang et al. 2012). This can also be utilized as the base for the identification of resistant genes present in the wild germplasm and their relatives collected from the North Eastern India which is the major gene hub for many desirable traits including yield, nutritional quality, resistance to pests and diseases, and tolerance to abiotic stresses like drought, salt, cold etc. The candidate genes identified for fusarium wilt resistance can be used either for the development of transgenic bananas or for screening the fusarium wilt resistant bananas developed through induced mutagenesis.

Propagation through conventional methods using suckers is easy but takes longer duration for the largescale production of planting material and further they serve as the potential source of transmission of fungal pathogens, nematodes, weevils, and viruses etc. (Nandhakumar et al. 2018). Therefore, the present study aimed at the rapid production of uniform and healthy planting material through development of a species-specific protocol using shoot tip explants. The planting material derived from the shoot tip explants could be comfortably used in transcriptome studies towards gene identification for fusarium wilt resistance.

\section{Materials And Methods}

\section{Plant Material}

A survey was conducted in Arunachal Pradesh of North Eastern India for collection of wild species. The sword suckers of the test cultivar M.laterita was collected and brought to ICAR - NRCB, Trichy and established in field gene bank. After sufficient multiplication of suckers, shoot meristems of approximately $5.0 \mathrm{~cm}^{3}$ in size were isolated from 2-3 months old "sword suckers" and they were used as explants in the present study.

\section{Media preparation}


MS medium supplemented with different combinations of auxins and cytokinins were prepared. The $\mathrm{pH}$ of the medium was adjusted to 5.8 with $1.0 \mathrm{M} \mathrm{NaOH}$ or $\mathrm{HCl}$. Prior to autoclaving, $0.8 \%$ agar was added to the medium. The medium was autoclaved at $121^{\circ} \mathrm{C}$ for $20 \mathrm{~min}$ at $15 \mathrm{psi}$. Among the cytokinins, Thidiazuron (TDZ) being thermo-labile, was added to the media through filter sterilization after autoclaving.

\section{Surface sterilization of the explant}

The explants were soaked in $100 \mu \mathrm{l} / \mathrm{L}$ Tween-20 for 10 mins followed by washing in running tap water for 20 mins to remove all traces of the detergent. Then the explants were taken to the laminar air flow chamber for surface sterilization. The explants were soaked in $4 \%(\mathrm{v} / \mathrm{v})$ sodium hypochlorite for $10 \mathrm{~min}$ followed by $0.1 \%(\mathrm{w} / \mathrm{v})$ mercuric chloride solution for 5 minutes with two sterile water rinsing in between.

\section{Establishment of culture}

The surface sterilized shoot tips were trimmed to a final size of $2-3 \mathrm{~cm}$ and initiated on full-strength MS medium supplemented with different hormonal combinations. All the cultures were maintained at $25 \pm 2^{\circ} \mathrm{C}$ under a 16-h photoperiod at a light intensity of 30-40 $\mu \mathrm{mol}$ photons $\mathrm{m}^{-2} \mathrm{~s}^{-1}$. The cultures were initially established by initiating the shoot tips in MS medium fortified with different concentrations of BAP (2 to $5 \mathrm{mg} / \mathrm{l})$ along with IAA $(0.5 \mathrm{mg} / \mathrm{l})$. Shoot bud formation was achieved by culturing in MS medium containing BAP $(3 \mathrm{mg} / \mathrm{l})+\mathrm{IAA}(0.5 \mathrm{mg} / \mathrm{l})$ along with different concentrations of TDZ $(0.1 \mathrm{mg} / \mathrm{l}$ to $0.5 \mathrm{mg} / \mathrm{l})$. Shoot multiplication was obtained by culturing in MS medium supplemented with different concentrations of BAP ( 2 to $5 \mathrm{mg} / \mathrm{l})$ along with IAA $(0.5 \mathrm{mg} / \mathrm{l})$ and $\mathrm{KIN}(0.25 \mathrm{mg} / \mathrm{l})$.

\section{Rooting and transplantation}

The shoots of 5-7 cm long were transferred to half MS medium supplemented with different concentrations of IBA $(0.5,1,1.5,2.0, \mathrm{mg} / \mathrm{l})$ and NAA $(0.5,1.0 \mathrm{mg} / \mathrm{l})$ along with $0.025 \%$ activated charcoal. Prior to hardening, the plantlets were gently removed from the vessel and washed with water to remove the traces of agar adhering to the plant. The pro trays were filled with the mixture of coco-peat and vermicompost in 2:1 ratio. The plantlets were treated with $0.1 \%$ fungicide for 30 seconds and transferred to pro-trays. The plants were maintained in glass house conditions during primary hardening. After primary hardening, the plants were transferred to polybags containing potting mixture comprising of 2:1:1 mix of red soil, vermicompost and sand and maintained in a $50 \%$ green shade-net for secondary hardening purpose.

\section{Observation and statistical analysis}

The days taken for greening of the shoot tips were recorded during the culture initiation phase. Fresh weight gain was recorded during $2^{\text {nd }}$ and $3^{\text {rd }}$ subcultures. Days taken for multiple shoot formation and total number of shoots formed after five subcultures were recorded during the shoot proliferation stage. 
The days taken for root initiation, number of roots and leaves produced and length of the longest root were recorded during the rooting stage.

Five replications were maintained for each treatment. The values are expressed as mean of five replicates $(n=5) \pm$ SE. The data were analyzed using One-way Analysis of Variance (ANOVA) using statistical package SPSS 17. Mean values were separated by Duncan's multiple range test (DMRT) at $5 \%$ probability level.

\section{Results}

\section{Initial establishment of M.laterita shoot tips}

Though different explants such as shoot tip, zygotic embryos, somatic embryos, male flower buds are normally used for the regeneration of plantlets in banana, shoot tip is the most common explant which was used in the present study for the development of species specific tissue culture protocol for M.laterita. The explants remained free of fungal and bacterial contamination resulting in the establishment of axenic cultures and turned green and swollen after a week of culturing indicating their successful establishment.

After 5-10 days of initiation of M.laterita in the MS medium with six different combinations of BAP and IAA, the shoot tips turned from creamy white to greenish colour and produced mostly single shoots. The treatments showed significant differences and earliest greening of shoot tips and their growth was recorded in T2 (5.66 days) followed by T3 (6.10 days) both of which were on par. The greening was delayed in control (10.72 days).

\section{Shoot bud induction in M.laterita as influenced by TDZ}

Damaging of apical meristem by giving cross cuts and sub-culturing them twice in MS medium with different concentrations of TDZ and $3 \mathrm{mg} / \mathrm{I} \mathrm{BAP}$ and $0.5 \mathrm{mg} / \mathrm{I} \mathrm{IAA}$ resulted in the formation of visible adventitious shoot buds. Appearance of several stunted, small adventitious buds on the surface of fleshy bulging structures is an indication of shoot bud formation. The optimal media for shoot bud formation was found to be T2 $(0.2 \mathrm{mg} / \mathrm{l} \mathrm{TDZ})$ where the weight gain after six weeks was $4.75 \mathrm{~g}$ followed by T3 $(0.3$ $\mathrm{mg} / \mathrm{l} \mathrm{TDZ})$. But after 9 weeks, the maximum weight gain was observed in T3 (7.36 g) followed by T2 (6.68g).

\section{Hormonal combinations affect shoot multiplication in M.laterita}

Days taken for multiple shoot initiation and number of shoots produced per explant at the end of seventh subculture was recorded (Fig 2). MS media supplemented with BAP $(3.0 \mathrm{mg} / \mathrm{I})$ and IAA $(0.5 \mathrm{mg} / \mathrm{I})$ was considered optimum as earlier multiple shoot initiation (31.80 days) and maximum number of shoots per explant (25.40) was produced in T2 followed by T3 both of which were on par with each other. The minimum number of shoots per explant was produced in control though the multiple shoot initiation was earlier when compared to other treatments containing kinetin in addition to BAP and IAA. 


\section{Rooting and hardening of M.laterita plantlets derived from shoot tip explants}

Induction of healthy root system from the regenerated shoots is an essential part for successful development of plantlets. Single shoots obtained during the proliferation phase were further cultured in MS basal medium supplemented with four different concentrations of IBA $(0.5,1.0,1.5$ and $2.0 \mathrm{mg} / \mathrm{l})$ along with two different concentrations of NAA $(0.5$ and $1.0 \mathrm{mg} / \mathrm{l})$ for root induction. IBA and NAA exerted significant effects on number of days taken for root initiation, number of roots produced per shoot, length of the longest root $(\mathrm{cm})$ and number of leaves (Table 2). As the concentration of IBA and NAA was increased, there was a proportionate increase in the root number, root length and number of leaves except T8. The data was recorded after four weeks of inoculation and revealed that IBA $(1.5 \mathrm{mg} / \mathrm{I})$ and NAA $(1.0 \mathrm{mg} / \mathrm{l})$ when added in MS media proved superior over other treatments for almost all rooting parameters. The next best treatment was found to be $T 6$ containing $1.0 \mathrm{mg} / \mathrm{l}$ each of IBA and NAA.

\section{Discussion}

A multitude of research on banana and plantains is in progress with respect to crop improvement strategies. Though genetic manipulation towards imparting desirable characteristics like pest and disease resistance, enhancement of nutritional and yield attributes is being attempted in a sustained manner, many biotic and abiotic stresses are still in existence, affecting the banana cultivation. In the recent days, Panama wilt is the major threat challenging banana cultivation across the globe. Identification of genes imparting resistance to Fusarium wilt disease is very much essential for the development of wilt resistant bananas as the existing chemical control measures could not effectively manage the disease. The wild Musa spp. are reported to harbor genes for major biotic and abiotic stresses many of which remains unexplored. One such wild species is Musa laterita which needs to be investigated for the presence of Fusarium wilt resistant genes for which transcriptome analysis remains as the most appropriate method. However, there are no reports in India on transcriptomic profile of Musa laterita, the wild species commonly found in North Eastern India.

Commercial micropropagation of ornamental banana is not done in an extensive manner owing to poor multiplication rates compared to edible bananas (Natarajan et al. 2019). Reports are few on micro propagation of M.laterita. (Duangkongsan and Promtab 2014) reported only minimum number shoots per explant in MS medium supplemented with $3 \mathrm{ppm}$ of BAP. Therefore, attempts have been made in the present study to regenerate uniform clonal plants of $M$.laterita through the development of an efficient micro propagation protocol using shoot tip explants.

The explants collected from field grown bananas usually harbor many soil-borne pathogens and other contaminants that hinder the in vitro culture. Therefore, it is highly essential to eliminate them before inoculation for the establishment of axenic cultures. Aseptic cultures of wild species Musa laterita'were established following the protocol adopted by (Saraswathi et al. 2014). Plant growth regulators, especially the cytokinins are the most crucial components of any plant tissue culture, as the culture establishment and shoot growth is highly dependent on it (Gubbuk and Pekmezci 2004). Adenine-based 
cytokinins are commonly used in several banana genotypes (Musa spp.) for in vitro propagation. N6benzylaminopurine (BAP) is the most commonly preferred cytokinin (Venkatachalam et al. 2006; Bairu et al. 2008; Jafari et al. 2011).

Development of in vitro culture requires perfect environment for the quick adoption of explant under in vitro conditions. Hence, the present study or investigation tried to fix up the optimum growth regulator combinations for various stages of micropropagation so as to facilitate the rapid production of uniform planting materials of M.laterita for use in transcriptomic analysis. Normally MS medium with BAP is enough for initial establishment of banana as reported by several workers (Muhammad et al. 2007 and Saraswathi et al. 2014). But the initial establishment of axenic cultures in Musa laterita has been achieved in MS media containing BAP $(3.0 \mathrm{mg} / \mathrm{l})$ and IAA $(0.5 \mathrm{mg} / \mathrm{l})$ where the explants turned green and swollen indicating their successful establishment. These are in line with the findings of (Karule et al. 2016).

TDZ which belongs to the diphenylurea group of cytokinins is reported to be superior to BAP (Waman et al. 2016) in overcoming apical dominance, promoting lateral bud break and adventitious shoot induction in plant tissue culture. In the present study, the medium used for initial establishment could not induce any adventitious buds, therefore TDZ was used along with BAP and IAA that influenced the shoot bud production positively which was evident from the visible small adventitious buds formed. Sub-culturing of single shoot obtained during the initial establishment twice in MS media containing $0.3 \mathrm{mg} / \mathrm{I} \mathrm{TDZ}$ along with BAP ( $3 \mathrm{mg} / \mathrm{l})$ and IAA $(0.5 \mathrm{mg} / \mathrm{l})$ after damaging of apical meristem by giving cross cuts resulted in the formation of small adventitious buds leading to higher fresh weight gain in T3 after nine weeks of incubation. The potential of TDZ in improving the propagation efficiency in recalcitrant varieties like Elakki Bale has earlier been reported by (Bohra et al. 2014). The synergistic effect of cytokinins and auxins might have induced the shoot bud formation in recalcitrant M.laterita as reported earlier (Gubbuk and Pekmezci 2004; Shirani et al. 2009; Ngomuo et al. 2014). The superiority of TDZ might be correlated to the synthesis of endogenous adenine based cytokinins and its minimum sensitivity to the degrading enzymes present in the plant system (Huetteman and Preece 1993). The variation in the activity of different cytokinins is due to the variation in the uptake rates (Blakesly 1991), varied rates of translocation to meristematic regions, metabolic processes leading to their degradation and conjugation with sugars or aminoacids to form biologically inert compounds (Kaminek 1992). TDZ at higher concentrations was found to suppress the shoot bud formation which is ascertaining the fact that cytokinins have an inhibitory effect at higher concentrations (Kahia et al. 2015).

In the present investigation, the cytokinins viz., benzyl amino purine (BAP), kinetin along with indole acetic acid (IAA) were tested at various concentrations for shoot multiplication to confirm the earlier results of (Wong et al. 1986) and (Arinaitwe et al. 2000) who reported the combination of BAP and kinetin to be highly potent in multiple shoot formation than other cytokinins. Contrarily, combination of cytokinins i.e., BAP and kinetin due to their supra-optimal levels reduced multiple shoot formation as reported earlier by (Madhulatha et al. 2004) in banana cv. Nendran. BAP at a lower concentration of 3 $\mathrm{mg} / \mathrm{l}$ gave better results in terms of earliness and multiple shoot production as reported earlier (Lohidas 
and Sujin 2015). This might be due to the action of BAP which reduced apical dominance and induced both axillary and adventitious shoot formation in meristematic explants of banana (Jafari et al. 2011). MS media supplemented with cytokinin namely BAP $(3.0 \mathrm{mg} / \mathrm{l})$ along with IAA $(0.5 \mathrm{mg} / \mathrm{l})$ was found best with respect to days taken for multiple shoot initiation (31.80 days) and maximum number of shoots produced per explant (25.40) as reported earlier (Gubbuk and Pekmezci 2004; Resmi and Nair 2007; Jafari et al. 2011 and Karule et al. 2016). This might be attributed to the precise manipulation of cytokinin and auxin levels which changed the growth pattern positively under in vitro conditions (Dixon and Gonzales 1994).

The multiple shoots obtained through in vitro culture requires sufficient root length prior to their transfer to the ex-vitro environment for sustained growth and development. Auxins like IBA, IAA, NAA are the most commonly used hormones to induce rooting in banana micro-shoots (Molla et al. 2004; Saraswathi et al.

2014 and Kahia et al. 2015). Hence, for root initiation and growth, the MS media was supplemented with various concentrations of auxins like IBA and NAA were tested. As the concentrations of IBA and NAA were increased, there was a proportionate increase in root number, root length and leaves produced as reported by (Karule et al. 2016). There was an inhibitory effect when the IBA concentration was increased beyond $1.5 \mathrm{mg} / \mathrm{l}$. This is in conformity with the findings of (Lohidas and Sujin 2015) who reported an inhibitory effect of IBA at higher concentrations beyond $2 \mathrm{mg} / \mathrm{l}$. The variation witnessed in growth regulator requirement might be due to the differences in the genotype. In addition to auxins, activated charcoal $0.025 \%$ was added to the rooting media as it was reported to promote rooting in banana. This might be due to the fact that it causes irreversible adsorption of inhibitory compounds, decrease in the accumulation of toxic metabolites inclusive of phenolics (Thomas 2008) thereby stimulating plant growth in addition to rooting.

Tissue culture plantlets are the base material required for any transcriptome analysis. At five-leaf stage, roots were sampled as reported earlier for transcriptome analysis of Musa acuminata L. to study its response to low-potassium stress (Xu et al. 2019), infection by tropical race 4 of Fusarium oxysporum $\mathrm{f}$. sp. cubense (Munusamy et al. 2017). Similar kind of sampling has been reported in tea plant (Gao et al. 2019), to study differentially expressed genes in tissues during dedifferentiation and root redifferentiation. Likewise, differentially expressed miRNAs were analysed between Fusarium wilt-resistant and susceptible banana varieties (Song et al. 2016) using tissue culture plantlets. Hence in this study, we aimed to develop disease free quality plantlets which are to be utilized in the transcriptomic studies against Fusarium wilt.

\section{Conclusion}

The present investigation has resulted in the development of an efficient protocol for the in vitro regeneration of M.laterita that enabled the production of uniform planting material for use in transcriptome analysis.

\section{Declarations}




\section{Competing interests}

The authors declare no competing interests

Ethics approval - Not applicable

Consent to participate (include appropriate statements)

All the authors gave explicit consent to submit and that they obtained consent from the responsible authorities at the institute.

Consent for publication (include appropriate statements)

The article has not been submitted simultaneously for publication in any other journal

Availability of data and material (data transparency)

Data/Results/Ideas given in the paper are entirely the outcome of our research work

Code availability (software application or custom code) - Not applicable

\section{Acknowledgements}

The authors gratefully acknowledge the financial support offered by the Indian Council of Agriculture Research, New Delhi and the infrastructure provided by the Director, ICAR-National Research Centre for Banana, Tiruchirappalli.

\section{Author's contribution statement}

All authors contributed to the study conception and design. Marimuthu Somasundaram Saraswathi and Subbaraya Uma designed the study. Jayakumar Mahendran and Murugesan Umabharathi conducted the experiments. Palani durai and Chinnadurai Karthi responsible for the collection of M.laterita from NE region of India and their maintenance in the field gene bank. Arumugam Palanivelu Salini and Jayakumar Mahendran analysed data. Jayakumar Mahendran prepared the first draft. All authors reviewed the manuscript.

\section{References}

Arinaitwe G, Rubaihayo PR, Magambo MJS (2000) Proliferation rate effects of cytokinins on banana (Musa spp.) cultivars. Sci Hortic 86:13-21

Bairu MW, Strik WA, Dolezal K, Staden JV (2008) The role of topolins in micropropagation and somaclonal variation of banana cultivars 'Williams' and Grand Naine (Musa spp. AAA). Plant Cell Tiss Org Cult 95:373-379 
Blakesly D (1991) Uptake and metabolism of 6-benzyladenine in shoot cultures of Musa and Rhododendron. Plant Cell Tiss Org Cult 25:69-74

Bohra P, Waman A, Sathyanarayana BN, Umesha K, Balakrishna G (2014) Influence of different growth regulators on in vitro multiplication of mixed diploid Banana (Musa AB). Proceedings of the National Academy of Sciences, India, Section B: Biological Sciences. doi:10.1007/s40011-014-0435-3

Crouch JH, Vuylsteke D, Ortiz R (1998) Perspectives on the application of biotechnology to assist the genetic enhancement of plantain banana (Musa spp.). Plant Biotechnology 1:1-2

Duangkongsan W, Promtab W (2014) In vitro multiplication of Musa laterita Roxb. Journal of Agricultural Technology 10(5):1173-1181

Gao Y, Zhao M, Wu XH, Li D, Borthakur D, Ye JH, Zheng XQ, Lu JL (2019) Analysis of differentially expressed genes in tissues of Camellia sinensis during dedifferentiation and root redifferentiation. Scientific reports $9(1): 1-11$

Dixon RA, Gonzales RA (1994) Plant cell culture: a practical approach (No. 145). IRL press.

Gubbuk H, Pekmezci M (2004) In vitro propagation of some new banana types (Musa spp). Turkish Journal of Agriculture and Forestry 28(5):355-361

Hareesh VS, Joe A, Alappatt JP, Sabu M (2017) Musaceae of Andaman and Nicobar islands with two new synonyms and one distributional record. Rheedea 27:71-78

Herbert, JA and Marx, D (1990) Short-term control of Panama disease of bananas in South Africa. Phytophylactica 22(3):339-341

Huetteman CA, Preece J E (1993) Thidiazuron: A potent cytokinin for woody plant tissue culture. Plant Cell, Tissue and Organ Culture 33:105-109

Jafari N, Othman RY, Khalid N (2011). Effect of benzylaminopurine (BAP) pulsing on in vitro shoot multiplication of Musa acuminata (banana) cv Berangan. Afr J Biotechnol 10(13):2446-2450

Jamil FN, Tang CN, Saidi NB, Lai KS, Baharum NA (2019) Fusarium Wilt in Banana: Epidemics and Management Strategies. In Horticultural Crops. IntechOpen http://doi.org/10.5772/intechopen.89469

Kahia J, Ndaruhutse F, Waweru B, Bonaventure N, Mutaganda A, Sallah PY, Kariuki NP, Asiimwe T (2015) In vitro propagation of two elite cooking banana cultivars-FHIA 17 and INJAGI International Journal of Biotechnology and Molecular Biology Research 6(6):40-47

Kaliyappan R, Viswanathan S, Suthanthiram B, Subbaraya U, Saraswathi MS, Mayilvaganan M (2016) Evolutionary expansion of WRKY gene family in banana and its expression profile during the infection of root lesion nematode, Pratylenchus coffeae. PLoS one 11(9):p.e0162013 
Kaminek M (1992) Progress in cytokinin research. Trends Biotechnol 10:159-162

Karule P, Dalvi V, Kadu A, Chaudhari R, Subramaniam VR, Patil AB (2016) A commercial micropropagation protocol for Virupakshi (AAB) banana via apical meristem. African Journal of Biotechnology 15(11):401407

Lohidas J, Sujin D (2015) Effect of growth hormones in the micro propagation of banana cv. Matti. Plant Archives 15(1):307-314

Madhulatha P, Anbalagan M, Jayachandran S, Sakthivel N (2004) Influence of liquid pulse treatment with growth regulators on in vitro propagation of banana (Musa spp. AAA). Plant Cell Tissue and Organ Culture 76(2):189-191

Molla MMH, Khanam MD, Khatum MM, Al-Amin M, Malek MA (2004) In vitro rooting and ex vitro plantlet establishment of BARI banana as influenced by different concentrations of IBA. Asian Journal of Plant Sciences 3:196-199

Muhammad A, Rashid H, Hussain I, Naqvi SS (2007) Proliferation-rate effects of BAP and kinetin on banana (Musa spp. AAA Group) 'Basrai'. HortScience 42(5):1253-1255

Munusamy U, Mohd-Yusuf Y, Baharum NA, Zaidi K, Nor S, Abdullah A, Othman RY (2017) Analysis of banana transcriptome in banana roots in response to infection by tropical race 4 of Fusarium oxysporum f. sp. cubense. In: International Conference on Big data Applications in Agriculture, 5-6 December 2017 (ICBAA2017) pp. 75-81

Nandhakumar N, Kumar KK, Sudhakar D, Soorianathasundaram K (2018) Plant regeneration, developmental pattern and genetic fidelity of somatic embryogenesis derived Musa spp. J Genet Eng Biotechnol 16:587-598

Natarajan N, Sundararajan S, Ramalingam S, Chellakan PS (2020) Efficient and rapid in-vitro plantlet regeneration via somatic embryogenesis in ornamental bananas (Musa spp). Biologia 75(2):317-326

Nel B, Steinberg C, Labuschagne N Viljoen A (2007) Evaluation of fungicides and sterilants for potential application in the management of Fusarium wilt of banana. Crop Protection 26(4):697-705

Ngomuo M, Mneney E, Ndakidemi PA (2014) The in vitro propagation techniques for producing banana using shoot tip cultures. American Journal of Plant Sciences 5:1614-1622

Passos MA, de Cruz VO, Emediato FL, de Teixeira CC, Azevedo VCR, Brasileiro AC, Amorim EP, Ferreira CF, Martins NF, Togawa RC, Júnior GJP (2013) Analysis of the leaf transcriptome of Musa acuminata during interaction with Mycosphaerella musicola: gene assembly, annotation and marker development. BMC genomics 14(1):1-17 
Resmi L, Nair AS (2007) Plantlet production from the male inflorescence tips of Musa acuminata cultivars from South India. Plant Cell Tissue and Organ Culture 88(3):333-338

Sabu M, Joe A, Sreejith PE (2013) Musa velutina subsp markkuana (Musaceae): a new subspecies from northeastern India. Phytotaxa 92:49-54

Saraswathi MS, Praveena S, Uma S, Thangavelu R, Kannan G, Backiyarani S, Arivazhagan T (2014) Development of an efficient micropropagation technique for Musa cv. Udhayam (ABB). Indian Journal of horticulture 71(4):452-457

Shirani S, Mahdavi F, Maziah M (2009) Morphological abnormality among regenerated shoots of banana and plantain (Musa spp.) after in vitro multiplication with TDZ and BAP from excised shoot tips. African Journal of Biotechnology 8(21):5755-5761

Song S, Chen X, Huang D, Xu Y, Zeng H, Hu X, Xu B, Jin Z, Wang W (2016) Identification of miRNAs differentially expressed in Fusarium wilt-resistant and susceptible banana varieties. South African Journal of Botany 106:244-249

Stover RH (1962) Fusarial Wilt (Panama Disease) of Bananas and Other Musa Species; Commonwealth Mycological Institute: Kew, UK,; pp 117

Thomas T D (2008) The role of activated charcoal in plant tissue culture. Biotechnology advances 26(6):618-631

Uma S, Saraswathi MS, Mustaffa MM, Anushma P, Durai P (2014) "Description of wild Musa species endemic to Arunachala Pradesh in India" - National Research Center for Banana (ICAR), Thogamalai Road, Thayanur Post, Tiruchirappalli - 620102

Venkatachalam L, Thimmaraju R, Sreedhar RV, Bhagyalakshmi N (2006) Direct shoot and cormlet regeneration from leaf explants of 'Silk' banana (AAB). In Vitro Cellular \& Developmental Biology-Plant 42(3):262-269

Waman AA, Bohra P, Sathyanarayana BN (2016) Effect of various cytokinins and auxins on in vitro regeneration of plantlets from isolated bud clumps of Silk Banana var. Nanjanagud Rasabale (Musa AAB). Indian Journal of Plant Physiology 21(1):64-69

Wang Z, Zhang J, Jia C, Liu J, Li Y, Yin X, Xu B, Jin Z (2012) De novo characterization of the banana root transcriptome and analysis of gene expression under Fusarium oxysporum f. sp. cubense tropical race 4 infection. BMC genomics 13(1):1-9

Wong WC (1986) In vitro propagation of banana (Musa spp.): initiation, proliferation and development of shoot-tip cultures on defined media. Plant Cell Tiss Org Cult 6:159- 66 
Xu M, Zeng CB, He R, Yan Z, Qi Z, Xiong R, Cheng Y, Wei SS, Tang H (2019) Transcriptome analysis of banana (Musa acuminata L.) in response to low potassium stress. Agronomy 9(4):169

\section{Tables}

Table 1. Effect of BAP and IAA on initial establishment of $\boldsymbol{M}$. laterita

\begin{tabular}{|llll|}
\hline Initiation & BAP $(\mathrm{mg} / \mathrm{l})$ & IAA $(\mathrm{mg} / \mathrm{l})$ & Days taken for greening (Days) \\
\hline T1 & 2 & 0.5 & $6.48 \pm 0.14^{\mathrm{ab}}$ \\
\hline T2 & 3 & 0.5 & $5.66 \pm 0.16^{\mathrm{a}}$ \\
\hline T3 & 4 & 0.5 & $6.10 \pm 0.19^{\mathrm{a}}$ \\
\hline T4 & 5 & 0.5 & $7.12 \pm 0.14^{\mathrm{b}}$ \\
\hline Control & - & & $10.72 \pm 0.51^{\mathrm{C}}$ \\
\hline
\end{tabular}

Each value represents the mean \pm standard error of five replicates in last one column.

(Mean followed by the letters within the column indicating the level of significance at $\mathrm{P}<0.05$ by Duncan's Multiple Range Test (same letter within the column indicates the absence of difference; different letters indicate the significant difference; and combination of letters indicate no significant difference).

Table 2: Effect of different combinations of auxins on rooting of M.laterita 


\begin{tabular}{|c|c|c|c|c|c|c|}
\hline Treatment & $\begin{array}{l}\text { IBA } \\
(\mathrm{mg} / \mathrm{l})\end{array}$ & $\begin{array}{l}\text { NAA } \\
(\mathrm{mg} / \mathrm{l})\end{array}$ & $\begin{array}{l}\text { Days taken for root } \\
\text { initiation }\end{array}$ & $\begin{array}{l}\text { No. of } \\
\text { roots }\end{array}$ & $\begin{array}{l}\text { Length of the } \\
\text { longest root }(\mathrm{cm})\end{array}$ & $\begin{array}{l}\text { No. of } \\
\text { leaves }\end{array}$ \\
\hline T1 & 0.5 & 0.5 & $09.60 \pm 0.40^{\mathrm{bc}}$ & $\begin{array}{l}2.20 \pm \\
0.37^{c}\end{array}$ & $2.58 \pm 0.16^{f}$ & $\begin{array}{l}3.20 \pm \\
0.20^{\text {cd }}\end{array}$ \\
\hline T2 & 1 & 0.5 & $10.00 \pm 0.44^{\mathrm{bc}}$ & $\begin{array}{l}2.60 \pm \\
0.40^{\mathrm{bc}}\end{array}$ & $3.00 \pm 0.70^{e f}$ & $\begin{array}{l}3.00 \pm \\
0.44^{\text {cd }}\end{array}$ \\
\hline T3 & 1.5 & 0.5 & $11.80 \pm 0.58^{d}$ & $\begin{array}{l}3.20 \pm \\
0.20^{\mathrm{abc}}\end{array}$ & $3.80 \pm 0.37^{\mathrm{de}}$ & $\begin{array}{l}3.60 \pm \\
0.24^{\text {cd }}\end{array}$ \\
\hline T4 & 2 & 0.5 & $11.60 \pm 0.50 d$ & $\begin{array}{l}4.00 \pm \\
0.31^{\mathrm{ab}}\end{array}$ & $4.26 \pm 0.07^{\mathrm{cd}}$ & $\begin{array}{l}4.00 \pm \\
0.31^{\mathrm{bc}}\end{array}$ \\
\hline T5 & 0.5 & 1 & $14.40 \pm 0.50^{\mathrm{e}}$ & $\begin{array}{l}4.20 \pm \\
0.37^{a b}\end{array}$ & $4.70 \pm 0.41^{b c}$ & $\begin{array}{l}4.80 \pm \\
0.37^{\mathrm{ab}}\end{array}$ \\
\hline T6 & 1 & 1 & $08.60 \pm 0.40^{\mathrm{ab}}$ & $\begin{array}{l}4.40 \pm \\
0.50^{\mathrm{ab}}\end{array}$ & $5.38 \pm 0.35^{\mathrm{ab}}$ & $\begin{array}{l}5.40 \pm \\
0.40^{\mathrm{a}}\end{array}$ \\
\hline T7 & 1.5 & 1 & $07.60 \pm 0.24^{a}$ & $\begin{array}{l}4.60 \pm \\
1.20^{\mathrm{a}}\end{array}$ & $5.92 \pm 0.40^{\mathrm{a}}$ & $\begin{array}{l}5.00 \pm \\
0.54^{\mathrm{ab}}\end{array}$ \\
\hline T8 & 2 & 1 & $10.60 \pm 0.67^{\mathrm{cd}}$ & $\begin{array}{l}3.20 \pm \\
0.58^{\mathrm{abc}}\end{array}$ & $2.96 \pm 0.15^{e f}$ & $\begin{array}{l}3.00 \pm \\
0.24^{\text {cd }}\end{array}$ \\
\hline Control & - & & $17.00 \pm 0.70^{f}$ & $\begin{array}{l}2.80 \pm \\
0.37^{\mathrm{abc}}\end{array}$ & $2.36 \pm 0.07^{f}$ & $\begin{array}{l}2.80 \pm \\
0.37^{d}\end{array}$ \\
\hline
\end{tabular}

Each value represents the mean \pm standard error of five replicates in last four columns.

(Mean followed by the letters within the column indicating the level of significance at $\mathrm{P}<0.05$ by Duncan's Multiple Range Test (same letter within the column indicates the absence of difference; different letters indicate the significant difference; and combination of letters indicate no significant difference).

Figures 


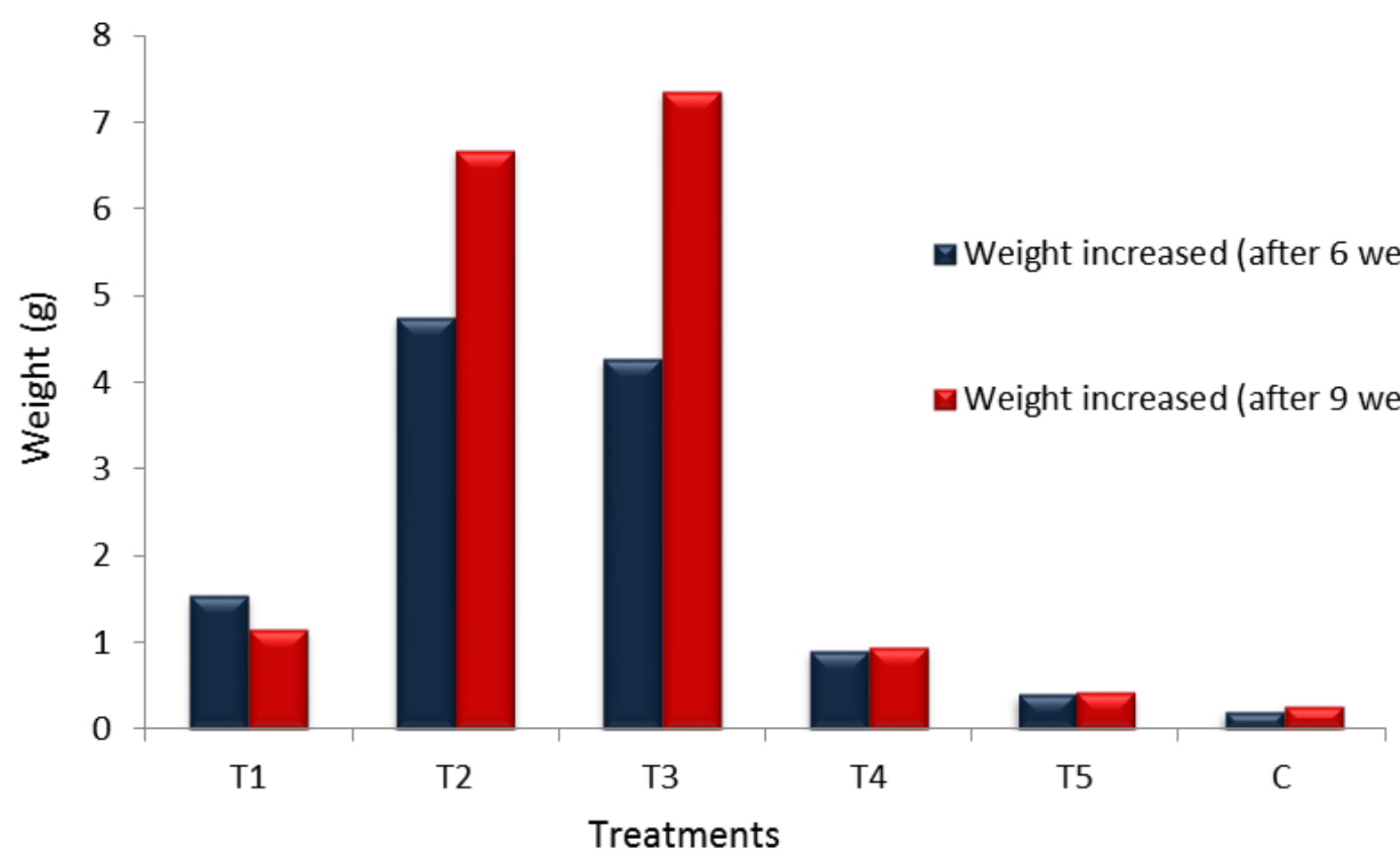

\section{Figure 1}

Effect of TDZ on shoot bud formation in M.laterita expressed in terms of weight gain
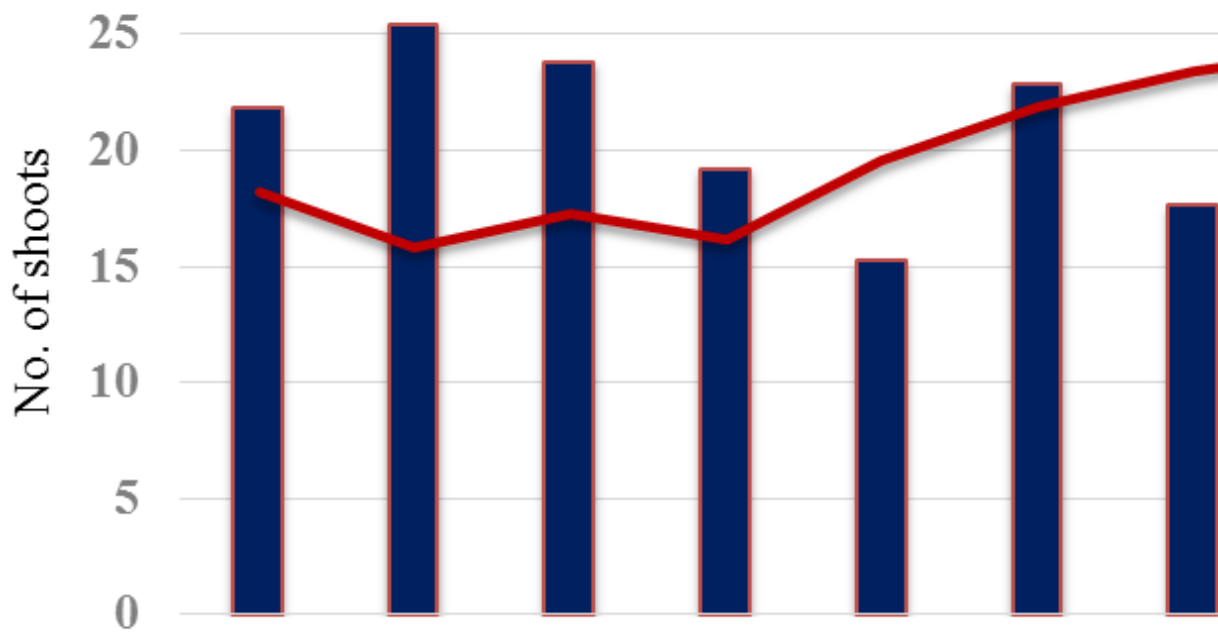

50

40

30

20 忿

10

$\mathbf{0}$

0

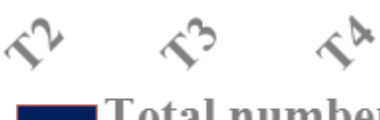

$4^{5}$

$r^{6}$

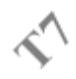

$r^{8}$

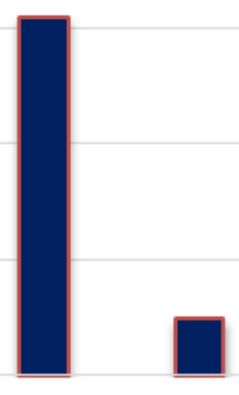

Total number of shoots formed per explant $\mathrm{C}^{\circ}$

—Days taken for multiple shoot induction 
Figure 2

Effect of different hormonal combinations on days taken for multiple shoot initiation and total number of shoots produced per explant
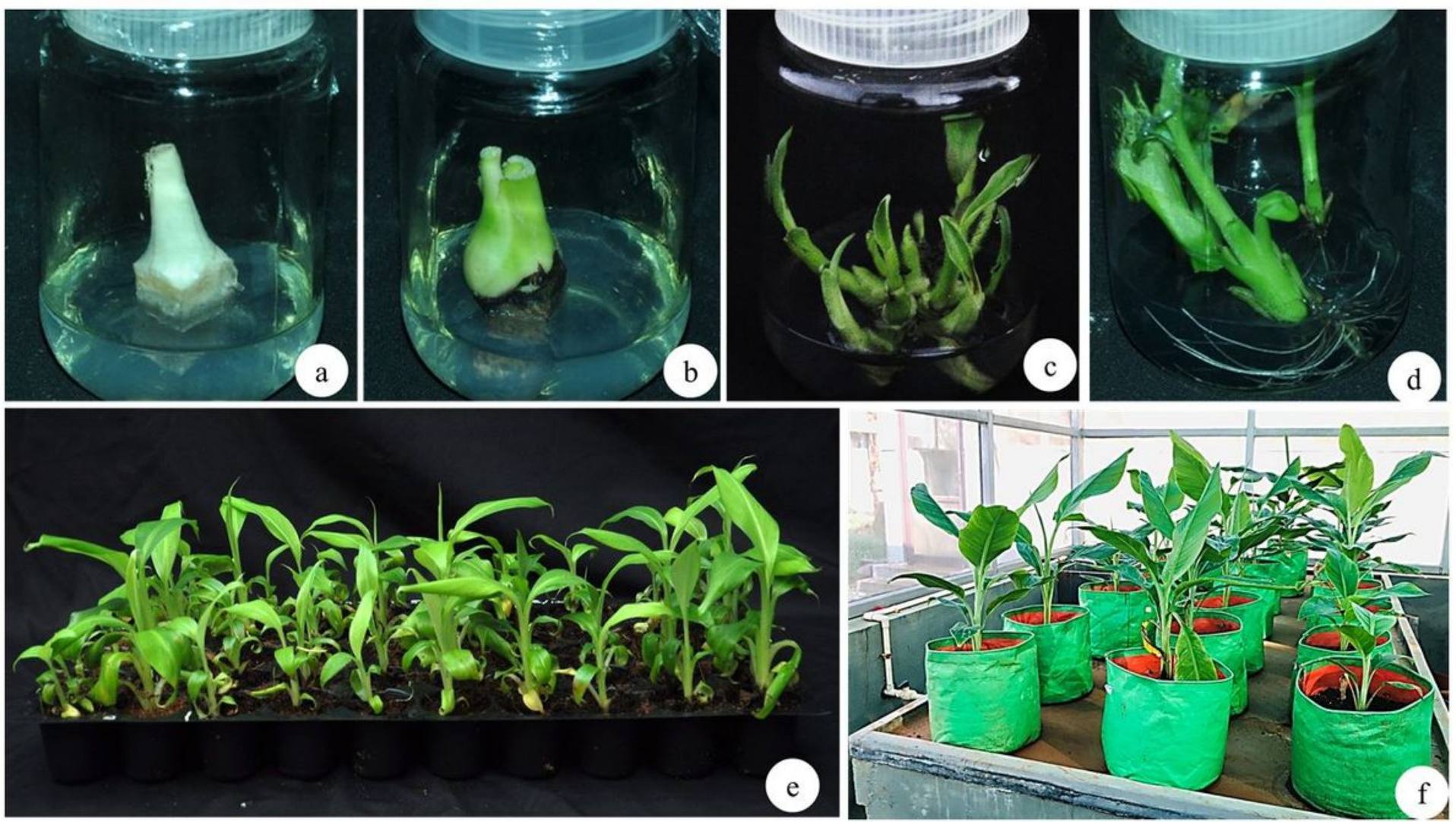

Figure 3

Stages of micropropagation in M.laterita using shoot tip explants. a) Inoculation; b) Greening of shoot tip; c) Multiplication; d) Rooting; e) Primary acclimatization; f) Secondary hardening. 